\title{
Syntheses and solid state structures of zinc (II) complexes with Bi-dentate $N$-(Aryl)imino-acenapthenone (Ar-BIAO) ligands
}

\author{
SRINIVAS ANGA, SUPRIYA REJ, KISHOR NAKTODE, TIGMANSU PAL and \\ TARUN K PANDA* \\ Department of Chemistry, Indian Institute of Technology Hyderabad, Ordnance Factory Estate, \\ Yeddumailaram 502 205, Telangana, India \\ e-mail: tpanda@iith.ac.in
}

MS received 19 May 2014; revised 18 June 2014; accepted 19 June 2014

\begin{abstract}
We have synthesized five zinc complexes of molecular formulae $\left[\mathrm{ZnCl}_{2}(2,6\right.$-dimethylphenyl$\mathrm{BIAO})]_{2}(\mathbf{1 a}),\left[\mathrm{ZnBr}_{2}(2,6-\text { dimethylphenyl-BIAO) }]_{2}(\mathbf{1 b}),\left[\mathrm{ZnI}_{2}(2,6-\text { dimethylphenyl-BIAO) }]_{2}(\mathbf{1 c}),\left[\mathrm{ZnBr}_{2}\left(\mathrm{mes}^{-}\right.\right.\right.\right.$ $\mathrm{BIAO})]_{2}(\mathbf{2 b})$ and $\left[\mathrm{ZnBr}_{2}(\operatorname{dipp}-\mathrm{BIAO})\right](\mathbf{3 b})$ with rigid unsymmetrical iminoacenaphthenone ligands, (2,6dimethylphenyl-BIAO) (1), (mesityl-BIAO) (2) and (2,6-diisopropylphenyl-BIAO) (3). The zinc complex 1a was prepared by the reaction of $\mathrm{ZnCl}_{2}$ and neutral (mesityl-BIAO) (1). However, complexes $\mathbf{1 b}, \mathbf{2 b}$ and $\mathbf{3 b}$ were obtained by the treatment of $\mathrm{ZnBr}_{2}$ and neutral ligands $\mathbf{1 - 3}$ respectively in 1:1 molar ratio in dichloromethane at ambient temperature. In a similar reaction of $\mathrm{ZnI}_{2}$ with (2,6-dimethylphenyl-BIAO) (1) in dichloromethane the corresponding iodo-complex 1c was obtained in good yield. All the zinc (II) complexes are characterized by FT-IR, ${ }^{1} \mathrm{H}$ and ${ }^{13} \mathrm{C}\left\{{ }^{1} \mathrm{H}\right\}$ NMR spectroscopic techniques. The solid state structures of the complexes $\mathbf{1 a}, \mathbf{1 b}$, 1c, $\mathbf{2 b}$ and $\mathbf{3 b}$ are confirmed by single crystal X-ray diffraction analysis. The molecular structures of complexes $\mathbf{1 a}, \mathbf{1 b}, \mathbf{1 c}$ and $\mathbf{2 b}$ reveal the dimeric nature of the complexes and subsequently the centre atom zinc is penta-coordinated to adopt distorted trigonal bipyramidal geometry around it. In contrast, the complex $\mathbf{3 b}$ is in monomeric in nature due to bulkier size of the ligand and zinc ion is tetra coordinated to adopt distorted tetrahedral geometry.
\end{abstract}

Keywords. Zinc(II); iminoacenathenone; penta- and tetra- coordinated; metallacycle; chelating ligands; steric crowding

\section{Introduction}

Zinc (II) complexes have been widely studied by several research groups for the past decades. The growing interest in the development of zinc catalysts for lactide polymerization $^{1-9}$ is one of the driving force. Recently $\mathrm{N}$ Zhao et al. have successfully reported some tridentate [NO] based ligands and their $\mathrm{Zn}(\mathrm{II}), \mathrm{Ta}(\mathrm{IV})$, $\mathrm{Ti}(\mathrm{IV}), \mathrm{Zr}(\mathrm{IV})$ complexes along with lanthanides, which are implemented as useful catalysts for a range of organic transformations. ${ }^{10-16}$ As an alternative method, by switching the ligand systems from tridentate to bidentate nature, tuning of catalytic activity of the metal complexes can be anticipated. Clearly, most of the applied metals (e.g., Pd, Rh, Ru, Ir) displayed difficulties by their low abundance, high price or toxicity. But zinc complexes are less toxic, has high abundance and low price. On the basis of that, research groups are now focusing on different zinc complexes for catalytic activity in organic transformations. V Bette et al. have

*For correspondence already reported the reduction of alkyl and aryl carbonyl by using zinc complex as a catalyst using Polymethylhydrosiloxane (PMHS). ${ }^{17}$ Besides the reduction of carbonyl, zinc complexes can also catalyze hydrosilylation and exhibit polymerization of olefins. In recent years, we have developed a series of rigid bi-dentate [NO]-based $\mathrm{N}$-(aryl) imino-acenapthenone (Ar-BIAO) ligands. ${ }^{18}$ This class of ligands can be obtained from the single condensation of acenaphthequinone and aryl amine moiety in 1:1 ratio in acidic medium (scheme 1) as a major product. In comparison with doubly condensed product (Ar-BIAN) first introduced by van Asselt and Elsevier, ${ }^{19}$ the Ar-BIAO ligand contains conjugated exocyclic carbonyl and imine groups. Secondly, the rigidity of the acenaphthene backbone forces the imine $\mathrm{N}$-atoms to remain in a fixed cis orientation with the exocyclic carbonyl group which favours the chelating coordination to a metal centre. Similar to Ar-BIAN, 2,2'-bipyridine and 1,10-phenanthroline ligands, ${ }^{20-22}$ the $\sigma$-donating and $\pi$-accepting properties of the Ar-BIAO ligands are observed due to the presence of exocyclic carbonyl and exocyclic imine groups 


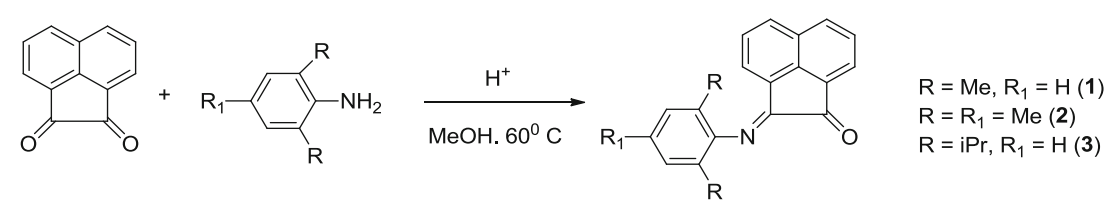

Scheme 1. Synthesis of (Ar-BIAO).

attached with rigid acenaphthene backbone. Herein, we present the full accounts of the synthesis and structural studies of five zinc complexes with Ar-BIAO ligands, $\quad\left[\mathrm{ZnCl}_{2}(2,6 \text {-dimethylphenyl-BIAO) }]_{2} \quad\right.$ (1a), $\left[\mathrm{ZnBr}_{2}(2,6 \text {-dimethylphenyl-BIAO) }]_{2} \quad(\mathbf{1 b}), \quad\left[\mathrm{ZnI}_{2}(2,6-\right.\right.$ dimethylphenyl-BIAO) $]_{2} \quad$ (1c), $\left[\mathrm{ZnBr}_{2} \text { (mes-BIAO) }\right]_{2}$ (2b) and $\left[\mathrm{ZnBr}_{2}\right.$ (dipp-BIAO)] (3b) and their UV-vis spectroscopic properties in solution and in solid state.

\section{Experimental}

\subsection{General Information}

All manipulations involving air- and moisture-sensitive compounds were carried out under argon using the standard Schlenk technique or argon-filled glove box. Dichloromethane and pentane were dried by standard methods and kept under molecular sieves prior to use. ${ }^{1} \mathrm{H}$ NMR (400 MHz) and ${ }^{13} \mathrm{C}\left\{{ }^{1} \mathrm{H}\right\}$ NMR $(100 \mathrm{MHz})$ spectra were recorded on a BRUKER AVANCE III400 spectrometer. BRUKER ALPHA FT-IR was used for FT-IR measurement. Elemental analyses were performed on a BRUKER EURO EA at the Indian Institute of Technology Hyderabad. Ar-BIAO ligands 1-3 were prepared according to the literature method ${ }^{18,23}$ and anhydrous $\mathrm{ZnCl}_{2}, \mathrm{ZnBr}_{2}$ and $\mathrm{ZnI}_{2}$ were purchased from Sigma Aldrich and used without further purification.

\subsection{Synthesis of $\left[\mathrm{ZnCl}_{2} \text { (2,6-dimethylphenyl-BIAO) }\right]_{2}$ (1a)}

In a dry degassed Schlenk tube, ligand $\mathbf{1}$ (200 mg, $0.70 \mathrm{mmol}$ ) was placed and about $10 \mathrm{~mL}$ of $\mathrm{CH}_{2} \mathrm{Cl}_{2}$ was added on to it. The solution was charged with anhydrous $\mathrm{ZnCl}_{2}(96 \mathrm{mg}, 0.70 \mathrm{mmol}$ ) at ambient temperature under inert atmosphere. The reaction mixture was stirred for another $12 \mathrm{~h}$ and then the reaction mixture was filtered using cannula filtration. Deep reddishorange coloured filtrate was evaporated to dryness under vacuo. The residue was re-dissolved in $2 \mathrm{~mL}$ chloroform and pentane (2 $\mathrm{mL})$ was layered on to it and kept for crystallization at $-40^{\circ} \mathrm{C}$. Single crystals of light orange colour were obtained after 2-3 days.
Yield: $239 \mathrm{mg}$ (81\%). FT-IR (selected frequency): $v=3057(\mathrm{Ar}-H), 2918(\mathrm{C}-H), 2854(\mathrm{C}-H), 1725$ $(\mathrm{C}=\mathrm{O}), 1645(\mathrm{C}=\mathrm{N}), 1584,1420,1280,1221,840$, $785 \mathrm{~cm}^{-1}$. ${ }^{1} \mathrm{H}$ NMR $\left(400 \mathrm{MHz}, \mathrm{CDCl}_{3}, 25^{\circ} \mathrm{C}\right): \delta=$ $8.38(\mathrm{t}, 2 \mathrm{H}, \mathrm{An}-H), 8.21(\mathrm{t}, 1 \mathrm{H}, \mathrm{An}-H), 7.96(\mathrm{t}, 1 \mathrm{H}$, An- $H), 7.56(\mathrm{t}, 1 \mathrm{H}$, An- $H), 7.19(\mathrm{~m}, 3 \mathrm{H}, \operatorname{Ar}-H)$, $6.78(\mathrm{~d}, 1 \mathrm{H}, \mathrm{An}-H), 2.21\left(\mathrm{~s}, 6 \mathrm{H}, \mathrm{CH}_{3}\right) \mathrm{ppm} ;{ }^{13} \mathrm{C}\left\{{ }^{1} \mathrm{H}\right\}$ NMR (100 MHz, $\left.\mathrm{CDCl}_{3}, 25^{\circ} \mathrm{C}\right): \delta 189.3(\mathrm{C}=\mathrm{O})$, $161.2(\mathrm{C}=\mathrm{N}), 147.4(\mathrm{Ar}-\mathrm{C}), 140.9(\mathrm{Ar}-\mathrm{C}), 135.0(\mathrm{Ar}-$ C), 132.1 (Ar-C), 130.0 (Ar-C), 128.8 (Ar-C), 128.4 (Ar-C), 127.4 (Ar-C), 127.3 (Ar-C), 127.0 (Ar-C), 126.8 (Ar-C), 126.5 (Ar-C), 125.4 (Ar-C), 124.6 (Ar-C), 122.6 (Ar-C), $19.7\left(\mathrm{CH}_{3}\right)$ ppm. Elemental analysis: $\left(\mathrm{C}_{42} \mathrm{H}_{32} \mathrm{Cl}_{10} \mathrm{~N}_{2} \mathrm{O}_{2} \mathrm{Zn}_{2}\right)\left(\mathbf{1 a} \cdot \mathrm{CHCl}_{3}\right)$ Calc. C 46.62, $\mathrm{H}$ 2.98, N 2.59; found C 46.22, H 2.61, N 2.33.

\subsection{Synthesis of $\left[\mathrm{ZnBr}_{2}(2,6 \text {-dimethylphenyl-BIAO) }]_{2}\right.$} (1b)

In a dry degassed Schlenk tube, ligand $1(200 \mathrm{mg}, 0.70$ mmol) was placed and about $10 \mathrm{~mL}$ of $\mathrm{CH}_{2} \mathrm{Cl}_{2}$ was added on to it. The solution was charged with anhydrous $\mathrm{ZnBr}_{2}(158 \mathrm{mg}, 0.70 \mathrm{mmol})$ at ambient temperature under inert atmosphere. The reaction mixture was stirred for another $12 \mathrm{~h}$ and then the reaction mixture was filtered using cannula filtration. Deep reddishorange coloured filtrate was concentrated to $2 \mathrm{~mL}$ and pentane $(2 \mathrm{~mL})$ was layered on to it and kept for crystallization at $-40^{\circ} \mathrm{C}$. Single crystals of light orange colour were obtained after 2-3 days. Yield: $271 \mathrm{mg}$ (76\%). FT-IR (selected frequency): $v=3065,2919,2851$, $1726(\mathrm{C}=\mathrm{O}), 1650(\mathrm{C}=\mathrm{N}), 1587,1434,1280,1221$, 777, $730 \mathrm{~cm}^{-1} .{ }^{1} \mathrm{H}$ NMR (400 $\mathrm{MHz}, \mathrm{CDCl}_{3}, 25^{\circ} \mathrm{C}$ ): $\delta 8.47(\mathrm{t}, 2 \mathrm{H}, \mathrm{An}-H), 8.27$ (d, 1H, An- $H), 8.05$ (dd, $1 \mathrm{H}, \mathrm{An}-H), 7.65$ (dd, $1 \mathrm{H}, \mathrm{An}-H), 7.30$ (m, 3H, Ar- $H$ ), $6.86(\mathrm{~d}, 1 \mathrm{H}, \mathrm{An}-H), 2.29\left(\mathrm{~s}, 6 \mathrm{H}, \mathrm{CH}_{3}\right) \mathrm{ppm} ;{ }^{13} \mathrm{C}\left\{{ }^{1} \mathrm{H}\right\}$ NMR $\left(100 \mathrm{MHz}, \mathrm{CDCl}_{3}, 25^{\circ} \mathrm{C}\right): \delta=190.7(\mathrm{C}=\mathrm{O})$, $162.7 \quad(\mathrm{C}=\mathrm{N}), 147.8 \quad$ (Ar-C), $142.2 \quad$ (Ar-C), 135.8 (Ar-C), 133.0 (Ar-C), 132.6 (Ar-C), 130.9 (Ar-C), 129.7 (Ar-C), 129.5 (Ar-C), 129.3 (Ar-C), 128.4 (ArC), 128.1 (Ar-C), 128.0 (Ar-C), 127.8 (Ar-C), 127.5 (Ar-C), 127.0 (Ar-C), 126.6 (Ar-C), 125.6 (Ar-C), 123.7 (Ar-C), $18.9\left(\mathrm{CH}_{3}\right)$ ppm. Elemental analysis: $\left(\mathrm{C}_{44} \mathrm{H}_{40} \mathrm{Br}_{4} \mathrm{Cl}_{8} \mathrm{~N}_{2} \mathrm{O}_{2} \mathrm{Zn}_{2}\right)\left(\mathbf{1 b} .2 \mathrm{CH}_{2} \mathrm{Cl}_{2}\right)$ Calc. C 38.78, H 2.96, N 2.06; found C 38.53 H 2.59, N 1.89. 


\subsection{Synthesis of $\left[\mathrm{ZnI}_{2}(2,6 \text {-dimethylphenyl-BIAO) }]_{2}\right.$} (1c)

In a dry degassed Schlenk tube, ligand 1 (200 mg, 0.70 mmol) was placed and about $10 \mathrm{~mL}$ of $\mathrm{CH}_{2} \mathrm{Cl}_{2}$ was added on to it. The solution was charged with anhydrous $\mathrm{ZnI}_{2}(224 \mathrm{mg}, 0.70 \mathrm{mmol})$ at ambient temperature under inert atmosphere. The reaction mixture was stirred for another $12 \mathrm{~h}$ and then the reaction mixture was filtered using cannula filtration. Deep reddishorange coloured filtrate was concentrated to $2 \mathrm{~mL}$ and pentane $(2 \mathrm{~mL})$ was layered on to it and kept for crystallization at $-40^{\circ} \mathrm{C}$. Single crystals of light orange colour were obtained after 2-3 days. Yield: $355 \mathrm{mg}, 84 \%$. FTIR (selected frequency): $v=3053,2918,2850,1705$ $(\mathrm{C}=\mathrm{O}), 1645(\mathrm{C}=\mathrm{N}), 1584,1420,1288,1221,833,775$ $\mathrm{cm}^{-1} .{ }^{1} \mathrm{H}$ NMR $\left(400 \mathrm{MHz}, \mathrm{CDCl}_{3}, 25^{\circ} \mathrm{C}\right): \delta=8.48(\mathrm{q}$, $2 \mathrm{H}, \mathrm{An}-H), 8.28(\mathrm{~d}, 1 \mathrm{H}, \mathrm{An}-H), 8.05$ (t, $1 \mathrm{H}, \mathrm{An}-H)$, 7.65 (t, 1H, An- $H$ ), 7.29 (m, 3H, Ar- $H), 6.87$ (d, 1H, An- $H), 2.36\left(\mathrm{~s}, 6 \mathrm{H}, \mathrm{CH}_{3}\right) \mathrm{ppm} ;{ }^{13} \mathrm{C}\left\{{ }^{1} \mathrm{H}\right\}$ NMR $(100$ $\left.\mathrm{MHz}, \mathrm{CDCl}_{3}, 25^{\circ} \mathrm{C}\right): \delta 189.7(\mathrm{C}=\mathrm{O}), 161.7(\mathrm{C}=\mathrm{N})$, 147.1 (Ar-C), 140.9 (Ar-C), 135.0 (Ar-C), 132.1 (ArC), 130.0 (Ar-C), 128.8 (Ar-C), 128.4 (Ar-C), 127.4 (Ar-C), 127.3 (Ar-C), 127.0 (Ar-C), 126.8 (Ar-C), 126.5 (Ar-C), 126.3 (Ar-C), 125.4 (Ar-C), 124.6 (Ar-C), 122.6 (Ar-C), $19.7\left(\mathrm{CH}_{3}\right)$ ppm. Elemental analysis: $\left(\mathrm{C}_{42} \mathrm{H}_{34} \mathrm{Cl}_{4} \mathrm{I}_{4} \mathrm{~N}_{2} \mathrm{O}_{2} \mathrm{Zn}_{2}\right)\left(\mathbf{1 c} . \mathrm{CH}_{2} \mathrm{Cl}_{2}\right)$ Calc. C 36.58, H 2.49, N 2.03; found C 35.98, H 2.13, N 1.85.

\subsection{Synthesis of $\left[\mathrm{ZnBr}_{2}(\mathrm{Mes}-\mathrm{BIAO})\right]_{2}(2 \boldsymbol{b})$}

In a dry degassed Schlenk tube, ligand 2 (200 mg, 0.67 mmol) was placed and about $10 \mathrm{~mL}$ of $\mathrm{CH}_{2} \mathrm{Cl}_{2}$ was added on to it. The solution was charged with anhydrous $\mathrm{ZnBr}_{2}$ (150 mg, $0.67 \mathrm{mmol}$ ) at ambient temperature under inert atmosphere. The reaction mixture was stirred for another $12 \mathrm{~h}$ and the reaction mixture was filtered using cannula filtration. Deep reddishorange coloured filtrate was concentrated to $2 \mathrm{~mL}$ and pentane $(2 \mathrm{~mL})$ was layered on to it and kept for crystallization at $-40^{\circ} \mathrm{C}$. Single crystals of light orange colour were obtained after 2-3 days. Yield: $280 \mathrm{mg} 80 \%$. FT-IR (selected frequency): $v=2920$, 2851, $1729(\mathrm{C}=\mathrm{O}), 1648(\mathrm{C}=\mathrm{N}), 1587,1435,1290$, 1224, 779, $730 \mathrm{~cm}^{-1} .{ }^{1} \mathrm{H}$ NMR $\left(400 \mathrm{MHz}, \mathrm{CDCl}_{3}\right.$ $\left.25^{\circ} \mathrm{C}\right): \delta 8.46(\mathrm{q}, 2 \mathrm{H}, \mathrm{An}-H), 8.28(\mathrm{~d}, 1 \mathrm{H}, \mathrm{An}-$ $H$ ), 8.03 (d, 1H, An- $H$ ), 7.60 (q, 1H, An- $H), 6.96$ (d, 1H, An- $H$ ), 6.91 (d, 2H, Ar- $H), 2.40(\mathrm{~s}, 3 \mathrm{H}, p-$ $\left.\mathrm{CH}_{3}\right), 2.34\left(\mathrm{~s}, 3 \mathrm{H}, o-\mathrm{CH}_{3}\right), 2.25\left(\mathrm{~s}, 3 \mathrm{H}, o-\mathrm{CH}_{3}\right) \mathrm{ppm}$; ${ }^{13} \mathrm{C}\left\{{ }^{1} \mathrm{H}\right\}$ NMR $\left(100 \mathrm{MHz}, \mathrm{CDCl}_{3}, 25^{\circ} \mathrm{C}\right): \delta 190.1$ $(\mathrm{C}=\mathrm{O}), 164.32(\mathrm{C}=\mathrm{N}), 140.2(\mathrm{Ar}-\mathrm{C}), 138.1(\mathrm{Ar}-\mathrm{C})$, 137.3 (Ar-C), 136.0 (Ar-C), 133.1 (Ar-C), 132.4 (ArC), 130.9 (Ar-C), 130.0 (Ar-C), 129.7 (Ar-C), 129.6
(Ar-C), 129.3 (Ar-C), 128.3 (Ar-C), 127.1 (Ar-C), 126.4 (Ar-C), 125.8, (Ar-C) 125.7 (Ar-C), 125.6 (ArC), $21.0\left(\mathrm{CH}_{3}\right), 18.9\left(\mathrm{CH}_{3}\right)$ ppm. Elemental analysis: $\left(\mathrm{C}_{46} \mathrm{H}_{42} \mathrm{Br}_{4} \mathrm{Cl}_{8} \mathrm{~N}_{2} \mathrm{O}_{2} \mathrm{Zn}_{2}\right)\left(2 \mathrm{~b} .2 \mathrm{CH}_{2} \mathrm{Cl}_{2}\right)$ Calc. C 39.78, H 3.05, N 2.02; found C 39.31, H 2.79, N 1.89.

\subsection{Synthesis of $\left[\mathrm{ZnBr}_{2}(\right.$ Dipp-BIAO) $\left.)\right](3 \boldsymbol{b})$}

In a dry degassed Schlenk tube, ligand 3 (200 mg, 0.58 mmol) was placed and about $10 \mathrm{~mL}$ of $\mathrm{CH}_{2} \mathrm{Cl}_{2}$ was added on to it. The solution was charged with anhydrous $\mathrm{ZnBr}_{2}$ (132 $\left.\mathrm{mg}, 0.58 \mathrm{mmol}\right)$ at ambient temperature under inert atmosphere. The reaction mixture was stirred for another $12 \mathrm{~h}$ and then the reaction mixture was filtered using cannula filtration. Deep reddishorange coloured filtrate was concentrated to $2 \mathrm{~mL}$ and pentane $(2 \mathrm{~mL})$ was layered on to it and kept for crystallization at $-40^{\circ} \mathrm{C}$. Single crystals of light orange colour were obtained after 2-3 days. Yield: $259 \mathrm{mg} 78 \%$. FTIR (selected frequency): $v=3063,2963,2927,1726$ $(\mathrm{C}=\mathrm{O}), 1649(\mathrm{C}=\mathrm{N}), 1586,1434,1274,778,725 \mathrm{~cm}^{-1}$. ${ }^{1} \mathrm{H}$ NMR $\left(400 \mathrm{MHz}, \mathrm{CDCl}_{3}, 25^{\circ} \mathrm{C}\right): \delta 8.40(\mathrm{t}, 2 \mathrm{H}, \mathrm{An}-$ $H), 8.21(\mathrm{~d}, 1 \mathrm{H}, \mathrm{An}-H), 7.98$ (t, $1 \mathrm{H}, \mathrm{An}-H), 7.55$ (q, $1 \mathrm{H}$, An- $H), 7.41$ (t, $1 \mathrm{H}, \operatorname{Ar}-H), 7.32(\mathrm{~d}, 2 \mathrm{H}, \operatorname{Ar}-H)$, $6.68(\mathrm{~d}, 1 \mathrm{H}, \mathrm{An}-H), 3.01$ (sept, $\left.2 \mathrm{H}, \mathrm{CH}\left(\mathrm{CH}_{3}\right)\right), 1.22$ (d, $\left.6 \mathrm{H}, \mathrm{CH}\left(\mathrm{CH}_{3}\right)\right), 0.75\left(\mathrm{~d}, 6 \mathrm{H}, \mathrm{CH}\left(\mathrm{CH}_{3}\right)\right) \mathrm{ppm} ;{ }^{13} \mathrm{C}\left\{{ }^{1} \mathrm{H}\right\}$ $\mathrm{NMR}\left(100 \mathrm{MHz}, \mathrm{CDCl}_{3}, 25^{\circ} \mathrm{C}\right): \delta 189.8(\mathrm{C}=\mathrm{O}), 162.3$ $(\mathrm{C}=\mathrm{N}), 146.9$ (Ar-C), 138.4 (Ar-C), 138.2 (Ar-C), 135.1 (Ar-C), 132.1 (Ar-C), 129.9 (Ar-C), 128.8 (ArC), 128.0 (Ar-C), 127.8 (Ar-C), 126.2 (Ar-C), 125.7 (Ar-C), 125.4 (Ar-C), 124.1 (Ar-C), 122.6 (Ar-C), 27.9 $(\mathrm{C}-\mathrm{H}), 23.9\left(\mathrm{CH}_{3}\right), 23.7\left(\mathrm{CH}_{3}\right)$ ppm. Elemental analysis: $\left(\mathrm{C}_{25} \mathrm{H}_{25} \mathrm{Br}_{2} \mathrm{Cl}_{2} \mathrm{NO} \mathrm{Zn}\right)\left(3 \mathrm{~b} .2 \mathrm{CH}_{2} \mathrm{Cl}_{2}\right)$ Calc. C 46.08, H 3.87, N 2.15; found C 45.71, H 3.43, N 1.99 .

\subsection{Single-crystal $x$-ray structure determinations}

Single crystals of compound $\mathbf{1 a}, \mathbf{1 b}, \mathbf{1 c}, \mathbf{2} \mathbf{b}$ and $\mathbf{3 b}$ were grown from a solution of $\mathrm{CH}_{2} \mathrm{Cl}_{2}\left(\mathrm{CHCl}_{3}\right.$ for 1a) and pentane under argon atmosphere at a temperature of $-40^{\circ} \mathrm{C}$. In each case a crystal of suitable dimensions was mounted on a CryoLoop (Hampton Research Corp.) with a layer of light mineral oil and placed in a nitrogen stream at 150(2) K. All measurements were made on a Agilent Supernova X-calibur Eos CCD detector with graphite-monochromatic $\mathrm{CuK} \alpha$ $(1.54184 \AA)$ and $\operatorname{MoK} \alpha(0.71073 \AA$, for $2 \mathbf{b})$ radiation. Crystal data and structure refinement parameters are summarized in the table 1 . The structures were solved by direct methods (SIR92) ${ }^{24}$ and refined on $F^{2}$ by full-matrix least-squares methods; using SHELXL$97 .{ }^{25}$ Non-hydrogen atoms were anisotropically refined. 


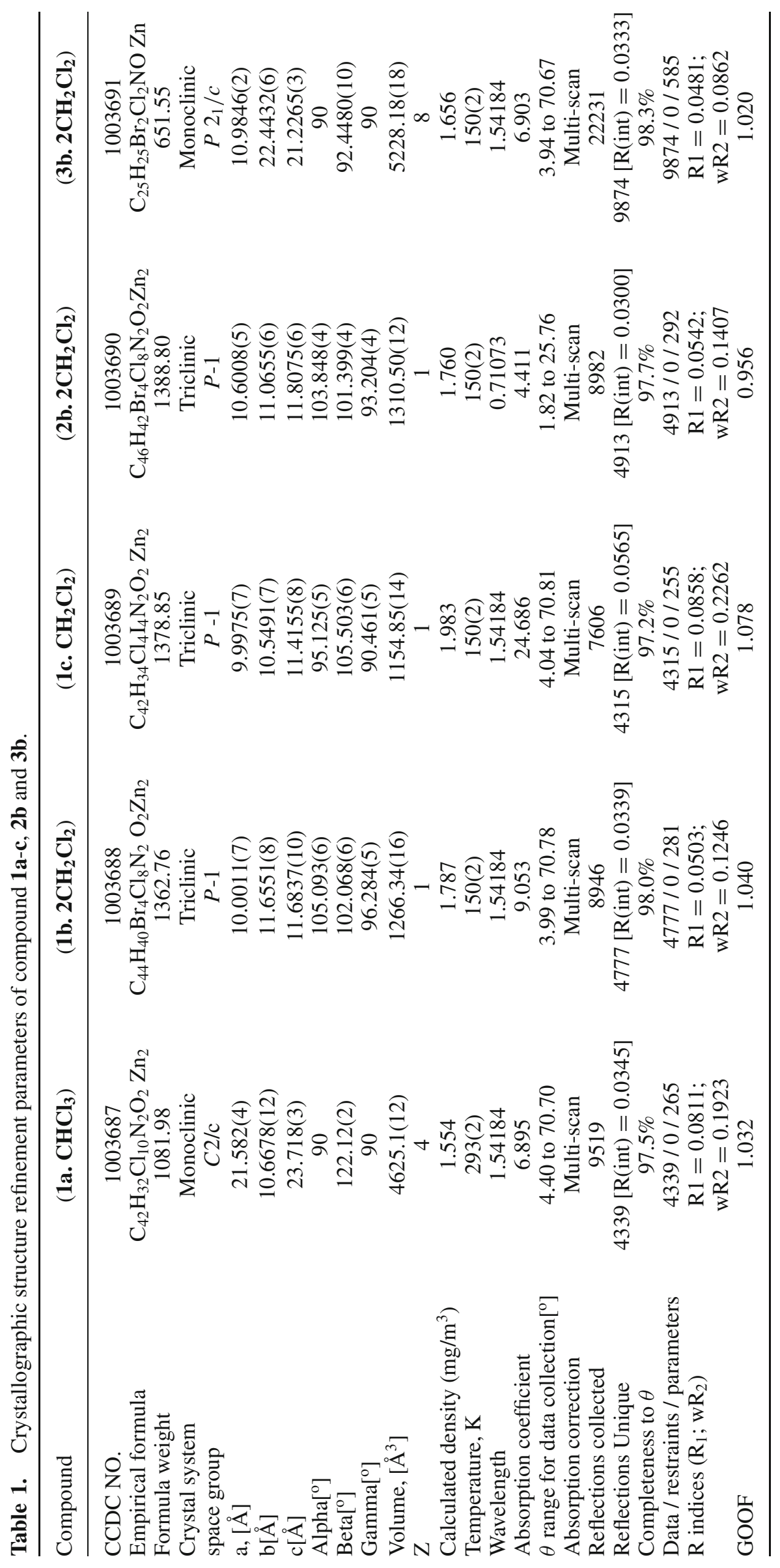


$\mathrm{H}$-atoms were included in the refinement on calculated positions riding on their carrier atoms. The function minimized was $\left[\sum w\left(F \mathrm{O}^{2}-F^{2}\right)^{2}\right](w=1 /$ $\left.\left[\sigma^{2}\left(F \mathrm{O}^{2}\right)+(a \mathrm{P})^{2}+b \mathrm{P}\right]\right)$, where $\mathrm{P}=\left(\operatorname{Max}\left(F \mathrm{O}^{2}, 0\right)+\right.$ $\left.2 F \mathrm{c}^{2}\right) / 3$ with $\sigma^{2}\left(F^{2}\right)$ from counting statistics. The function $R 1$ and $w R 2$ were $(\Sigma\|F \mathrm{o}|-| F \mathrm{c}\|) / \Sigma|F \mathrm{o}|$ and $\left[\Sigma w\left(F \mathrm{o}^{2}-F \mathrm{c}^{2}\right)^{2} / \Sigma\left(w F \mathrm{o}^{4}\right)\right],{ }^{1 / 2}$ respectively. The ORTEP-3 program was used to draw the molecule.

\section{Results and Discussion}

The 2, 6-dimethylphenyl-BIAO ligand (1) was treated with anhydrous zinc dichloride in dichloromethane in a 1:1 molar ratio to afford $\left[\mathrm{ZnCl}_{2}\right.$ (2,6-dimethylphenylBIAO) $]_{2}$ (1a) as orange solid in good yield (scheme 2). Other zinc complexes $\mathbf{1 b}, \mathbf{1 c}, \mathbf{2} \mathbf{b}$ and $\mathbf{3 b}$ were also isolated in similar reactions with respective ArBIAO ligands and zinc halides (scheme 2). The zinc complexes are soluble in THF, toluene, benzene and dichloromethane at room temperature. All the complexes were characterized by spectroscopic and analytical techniques. The solid state structures of all the complexes $\mathbf{1 a}-\mathbf{c}, \mathbf{2} \mathbf{b}$ and $\mathbf{3 b}$ were characterized by single crystal X-ray diffraction analysis.

In FT-IR spectra, all the compounds $\mathbf{1 a}-\mathbf{c}, \mathbf{2 b}$ and 3b show strong absorption bands at 1725, 1726, 1705, 1729 and $1726 \mathrm{~cm}^{-1}$ respectively for respective $\mathrm{C}=\mathrm{O}$ bond stretching, which is slightly deviated from the $\mathrm{C}=\mathrm{O}$ bond stretching frequencies of the corresponding ligands. ${ }^{18,23}$ The strong absorption bands at 1645 (1a), 1650 (1b), 1645 (1c), 1648 (2b) and $1649(3 \mathbf{b}) \mathrm{cm}^{-1} \mathrm{can}$ be assigned to $\mathrm{C}=\mathrm{N}$ bond stretching of the iminoacenapthenone moiety. In the ${ }^{1} \mathrm{H}$ NMR spectrum measured in $\mathrm{CDCl}_{3}$, compound 1a shows a sharp singlet signal at $2.21 \mathrm{ppm}$ which can be assigned to six protons from two methyl group at $o$-position of the phenyl group. For zinc dibromo and diiodo complexes $\mathbf{1 b}$ and $\mathbf{1 c}$, the respective methyl protons appeared as sharp singlet at 2.29 and $2.36 \mathrm{ppm}$ which is slightly low field shifted compared to that of 1a. However, the chemical shift values are in similar ranges and the slight differences can be accounted for by the gradual increase in sizes from chlorine to iodine atom attached to the zinc atom.

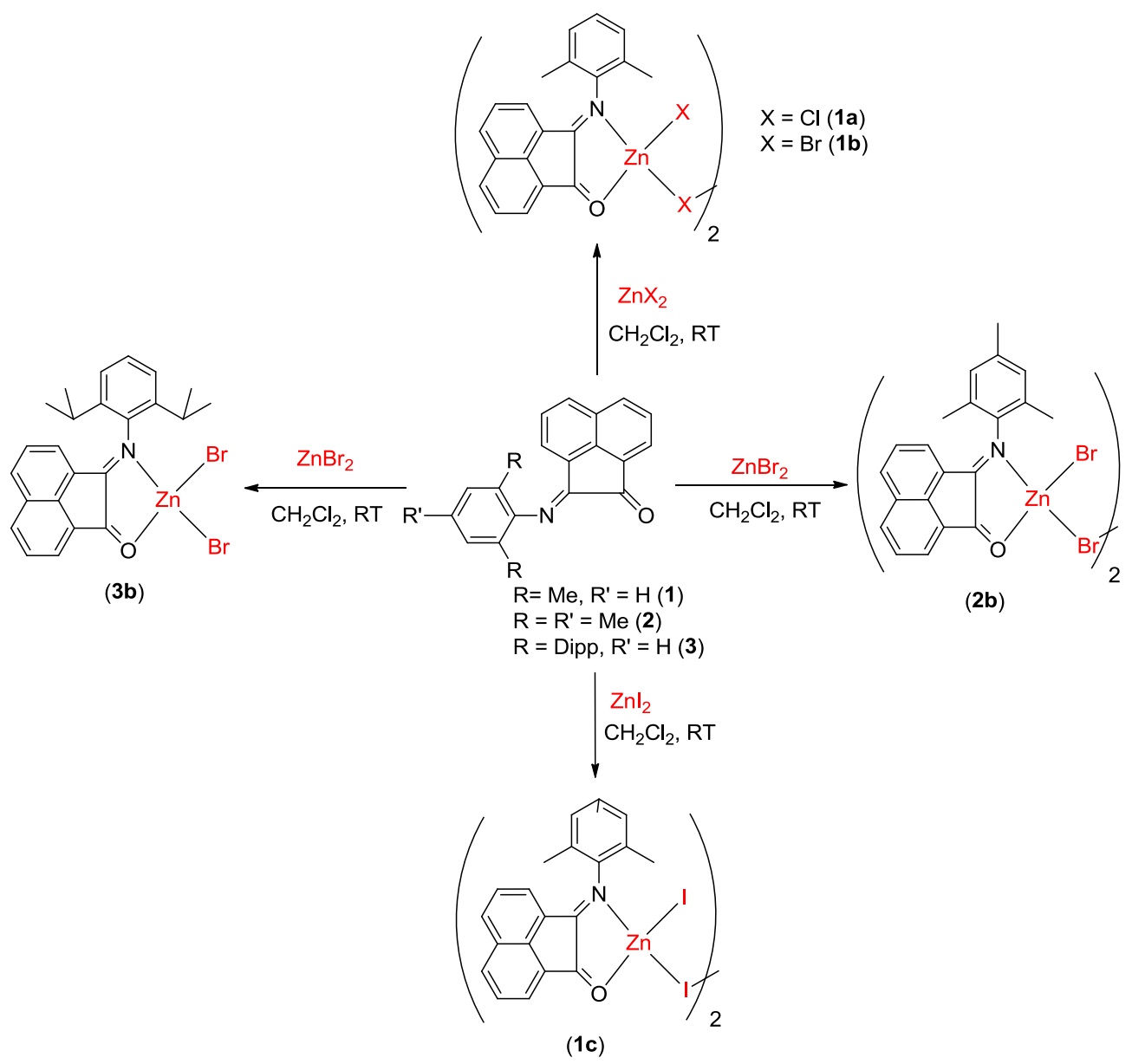

Scheme 2. Synthesis of zinc complexes of $\mathbf{1 a}-\mathbf{c}, \mathbf{2 b}$ and $\mathbf{3 b}$. 
However, these chemical shift values are slightly high field shifted with respect to the corresponding values of ligand 1 ( $\delta 2.04 \mathrm{ppm})$. The multiplets in the range of 6.68-8.48 ppm for the complexes 1a-c are due to the aromatic protons present in the phenyl group as well in the acenapthene moiety. Compound $\mathbf{2 b}$ which has mesityl-BIAO ligand, shows two sharp singlets at 2.34 and $2.25 \mathrm{ppm}$ in a 1:1 ratio and can be assigned to each of three methyl protons at $o$-positions of the phenyl group indicating the free rotation around the N(imine)$\mathrm{C}$ (mesityl) is restricted in NMR time scale. The singlet resonance signal at $2.40 \mathrm{ppm}$ for compound $\mathbf{2 b}$ is assigned to the three methyl protons of the mesityl group at $p$-position. These chemical shifts are in the similar range with that of free ligand $2(\delta 2.04$, six $o$ protons) and 2.35 (three $p$-protons $)^{23}$. The resonances of the aryl protons present in acenaphthene back bone and aryl ring are in the expected region in between 6.91-8.46 ppm similar with the corresponding values of complexes 1a-c and in well agreement with the free ligand $\mathbf{2}$. For compound $\mathbf{3 b}$, where more bulky 2,6disopropyl-BIAO ligand is present, two doublet signals at 0.74 and $1.22 \mathrm{ppm}$ in $1: 1$ ratio and the coupling constants of $(12 \mathrm{~Hz})$ can be assigned to the methyl protons attached to the isopropyl groups and this is in similar range with that of free ligand $\mathbf{3}$ ( $\delta 0.8$ and $1.1 \mathrm{ppm}){ }^{18}$ The characteristic septet at $3.01 \mathrm{ppm}$ corresponds to the resonance of the $\mathrm{CH}$ proton present in the isopropyl group is also observed slightly down field shifted than the corresponding value $(2.80 \mathrm{ppm})$ of ligand $\mathbf{3}$. The resonances of the protons of acenaphthene back bone and aryl ring for compound $\mathbf{3 b}$ are also in the expected region between 6.68-8.40 ppm and in good agreement with the free ligand 3. In ${ }^{13} \mathrm{C}\left\{{ }^{1} \mathrm{H}\right\}$ NMR spectra of the compounds $\mathbf{1 a}-\mathbf{c}, \mathbf{2} \mathbf{b}$ and $\mathbf{3 b}$, carbonyl carbon is mostly de-shielded and appear at $\delta=189.3,190.7$, $189.7,189.7$ and 189.8 ppm respectively. The imine carbon is observed at 161.2, 162.7, 161.7, 164.3 and 162.3 ppm respectively and the ipso carbon attached to nitrogen atom is observed at 147.4, 147.8, 147.1, 147.0 and 146.9 ppm respectively for complex $\mathbf{1 a - c}, \mathbf{2 b}$ and $\mathbf{3 b}$. These values are slightly shifted to the high field region compared to the respective Ar-BIAO ligands ${ }^{18,23}$ due to the attachment of zinc ion.

\subsection{Solid state structures}

The compounds $\mathbf{1 a}-\mathbf{c}, \mathbf{2} \mathbf{b}$ and $\mathbf{3 b}$ were re-crystallized from dichloromethane $\left(\mathrm{CHCl}_{3}\right.$ for 1a) and pentane (1:1) mixture and their molecular structures in the solid state were established by single crystal X-ray diffraction analysis. Compound 1a crystallizes in monoclinic space group $C 2 / \mathrm{c}$ with four molecules in unit cell along with one chloroform molecule as solvate. In contrast, complexes $\mathbf{1 b}, \mathbf{1 c}$ and $\mathbf{2 b}$ crystallize in triclinic space group $P-1$ having only one molecule in their respective unit cell along with dichloromethane molecule (two for $\mathbf{1 b}$ and $\mathbf{2 b}$ and one for $\mathbf{1 c}$ ) as solvents. The details of structural and refinement parameters of all the complexes $\mathbf{1 a - c}$ and $\mathbf{2 b}$ are given in table 1. The molecular structures of complexes $\mathbf{1 a - c}$ and $\mathbf{2 b}$ are shown in figure $1 \mathrm{a}-\mathrm{d}$ respectively.

The complexes $\mathbf{1 a - c}$ and $\mathbf{2 b}$ are dimeric in nature and two zinc ions are bridged through two $\mu_{2}$-halide ions in each case. In complexes 1a-c, the coordination polyhedron in each case is formed by the chelation of imine nitrogen, carbonyl oxygen atoms of the 2,6dimethyl-BIAO ligand and the halide atoms (three chloride for $\mathbf{1 a}$, three bromide for $\mathbf{1 b}$ and three iodide ions for 1c) attached to the zinc ion. In similar fashion, the coordination polyhedron of compound $\mathbf{2} \mathbf{b}$ is formed by the ligation of nitrogen and oxygen atoms present in mesityl-BIAO ligand and chloride ions. The complexes $\mathbf{1 a - c}$ and $\mathbf{2 b}$ are centrosymmetric due the presence of an inversion center in the middle of each of the molecule each of them form a four membered core $\mathrm{Zn} 1-\mathrm{Cl} 1-\mathrm{Zn} 1^{\mathrm{i}}-\mathrm{Cl1}{ }^{\mathrm{i}}$ (1a), Zn1-Br1-Zn1 ${ }^{\mathrm{i}}-\mathrm{Br} 1^{\mathrm{i}}$ (1) and 2b), and $\mathrm{Zn} 1-\mathrm{I} 1-\mathrm{Zn} 1^{\mathrm{i}}-\mathrm{I} 1^{\mathrm{i}}$ (1c). In addition, two more metallacycles are formed in each case Zn1-N1-C2-C1$\mathrm{O} 1$ and $\mathrm{Zn} 1^{\mathrm{i}}-\mathrm{N} 1^{\mathrm{i}}-\mathrm{C} 2^{\mathrm{i}}-\mathrm{C} 1^{\mathrm{i}}-\mathrm{O} 1^{\mathrm{i}}$ (1a), Zn1-N1-C1-C2-O1 and $\mathrm{Zn} 1^{\mathrm{i}}-\mathrm{N} 1^{\mathrm{i}}-\mathrm{C} 1^{\mathrm{i}}-\mathrm{C} 2^{\mathrm{i}}-\mathrm{O} 1^{\mathrm{i}}{ }$ (1) $), \mathrm{Zn} 1-\mathrm{N} 1-\mathrm{C} 9-\mathrm{C} 10-\mathrm{O} 1$ and $\mathrm{Zn} 1^{\mathrm{i}}-\mathrm{N} 1^{\mathrm{i}}-\mathrm{C}{ }^{\mathrm{i}}-\mathrm{C} 10^{\mathrm{i}}-\mathrm{O} 1^{\mathrm{i}}(\mathbf{1 c})$ and $\mathrm{Zn} 1-\mathrm{N} 1-\mathrm{C} 1-\mathrm{C} 2-$ $\mathrm{O} 1$ and $\mathrm{Zn} 1^{\mathrm{i}}-\mathrm{N} 1^{\mathrm{i}}-\mathrm{C} 1^{\mathrm{i}}-\mathrm{C} 2^{\mathrm{i}}-\mathrm{O} 1^{\mathrm{i}}(\mathbf{2 b})$. In these complexes, the geometry around each zinc ion can be best described either a distorted square pyramidal having $\mathrm{N} 1, \mathrm{O} 1, \mathrm{C} 11, \mathrm{Cl}^{\mathrm{i}}$ atoms for $\mathbf{1 a}, \mathrm{N} 1, \mathrm{O} 1, \mathrm{Br} 2, \mathrm{Br}{ }^{\mathrm{i}}$ for $\mathbf{1 b}$ and $\mathbf{2 b}, \mathrm{N} 1, \mathrm{O} 1, \mathrm{I} 1, \mathrm{I}^{\mathrm{i}}$ for $\mathbf{1 c}$ in the basal position and $\mathrm{Cl} 2$ (1a), Br1 (1b and 2b) and I1 (1c) atoms in the apical position or distorted trigonal bipyramidal having $\mathrm{N} 1 \mathrm{Cl1} \mathrm{Cl} 2$ atoms (for 1a), N1 Br1 Br2 (for $\mathbf{1 b}$ and $\mathbf{2 b}$ ) and N1 I1 I2 (for 1c) are in the equatorial position and O1, Cl1 ${ }^{\mathrm{i}}$ (1a), O1, Br2 ${ }^{\mathrm{i}}$ (1b and 2b), O1, $\mathrm{I}^{\mathrm{i}}$ (1c), atoms are in the apical position. Thus, all three complexes $\mathbf{1 a}-\mathbf{c}$ and $\mathbf{2 b}$ are examples of unusual penta- coordinated zinc atom. Such kind of unusual zinc complexes are rare in literature. ${ }^{26,27}$ The $\mathrm{Zn}-\mathrm{O}$ distances [2.469(2) $\AA$ (1a), 2.484(3) $\AA$ (1b), 2.392(8) $\AA$ (1c) and 2.414(3) (2b)] which are well in agreement with the zinc oxygen coordination bond rather covalent bond ( $\mathrm{Zn}-\mathrm{O}$ 1.976 (2) $\AA$ for covalent bond. ${ }^{27}$ The Zn1-N1 distances 2.087(3) $\AA$ (for 1a), 2.073(3) $\AA$ (for 1b), 2.104(8) $\AA$ (for $1 \mathbf{c}$ and $\mathbf{2 b}$ ) are in the range of the zinc nitrogen coordination bond as the similar $\mathrm{Zn}-\mathrm{N}$ distance 2.023(3) -2.34(3) $\AA$ is observed for $\mathrm{Zn}(\mathrm{mmpcd}) \mathrm{ClO}_{4}$ $\left.\left(\mathrm{mmpcd}=\mathrm{Me}_{2} \mathrm{pzCH}_{2}\right)_{2} \mathrm{NC}_{2} \mathrm{H}_{3} \mathrm{MeNHC}_{5} \mathrm{H}_{6} \mathrm{CSSCH}_{3}\right)$ 


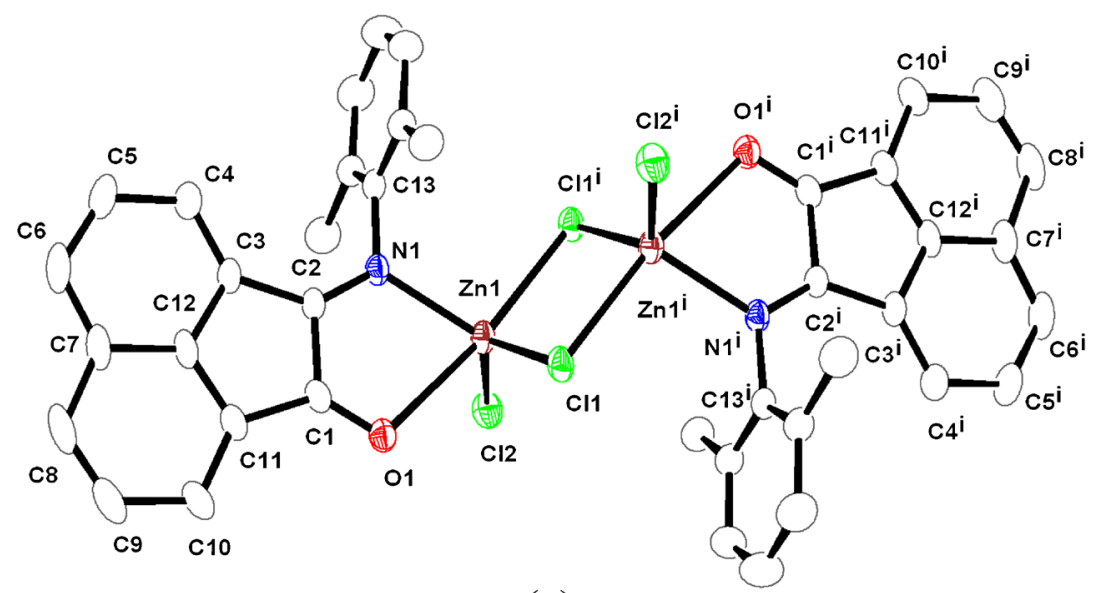

(a)

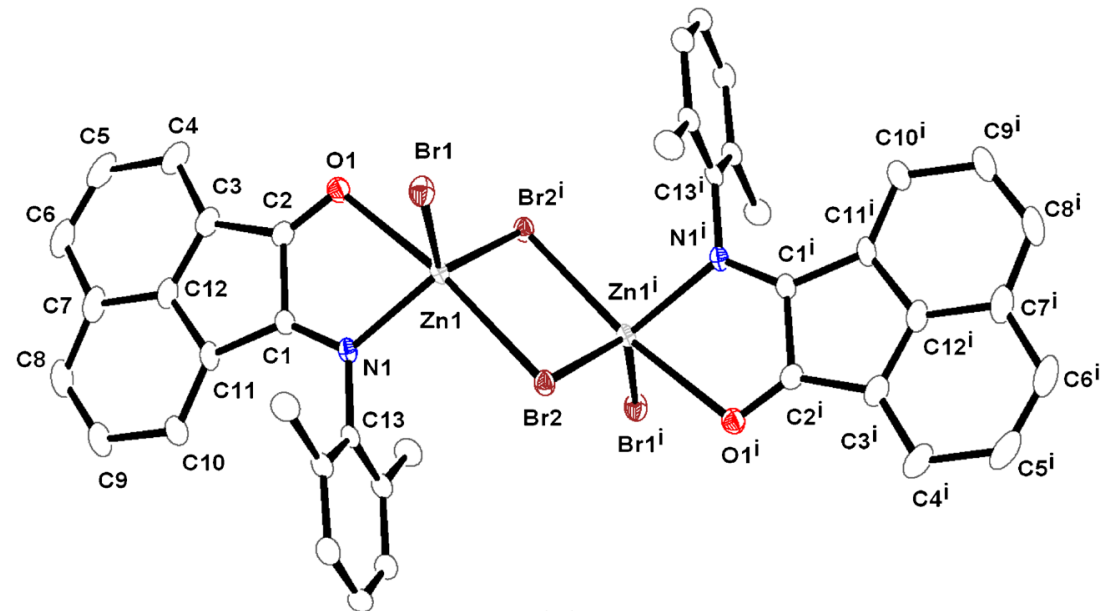

(b)

Figure 1. a-d Solid-state structures of $\mathbf{1 a - c}$ and $\mathbf{2 a}$ showing the atom labelling scheme omitting hydrogen atoms for clarity. Selected bond lengths in [Å]: 1a. $\mathrm{Zn}(1)-\mathrm{N}(1)$ 2.087(3), $\mathrm{Zn}(1)-\mathrm{Cl}(2)$ 2.2103(15), $\mathrm{Zn}(1)$ $\mathrm{Cl}(1)$ 2.3091(14), Zn(1)-Cl(1) ${ }^{\mathrm{i}} 2.4404(13), \mathrm{Zn}(1)-\mathrm{O}(1) 2.468(3), \mathrm{Cl}(1)-\mathrm{Zn}(1)^{\mathrm{i}}$ 2.4404(13), O(1)-C(1) 1.225(5), N(1)-C(2) 1.277(5), N(1)-C(13) 1.459(5), $\mathrm{C}(2)-\mathrm{C}(3)$ 1.462(5), C(2)-C(1) 1.522(6), C(1)-C(11) 1.469(6); Selected bond angles in $\left[{ }^{\circ}\right]$ : $\mathrm{N}(1)-\mathrm{Zn}(1)-\mathrm{Cl}(2) 116.30(12), \mathrm{N}(1)-\mathrm{Zn}(1)-\mathrm{Cl}(1)$ 115.46(11), $\mathrm{Cl}(2)-\mathrm{Zn}(1)-\mathrm{Cl}(1)$ 124.18(5), N(1)-Zn(1)-Cl(1) ${ }^{\mathrm{i}}$ 96.67(10,) $\mathrm{Cl}(2)-\mathrm{Zn}(1)-\mathrm{Cl}(1)^{\mathrm{i}}$ 104.78(5), $\mathrm{Cl}(1)-\mathrm{Zn}(1)-\mathrm{Cl}(1)^{\mathrm{i}}$ 88.50(4), N(1)-Zn(1)-O(1) 74.84(12), Cl(2)$\mathrm{Zn}(1)-\mathrm{O}(1)$ 89.41(9), Cl(1)-Zn(1)-O(1) 84.97(9), Cl(1) $-\mathrm{Zn}(1)-\mathrm{O}(1)$ 165.68(9,) $\mathrm{Zn}(1)-\mathrm{Cl}(1)-\mathrm{Zn}(1)^{\mathrm{i}}$ 91.50(4), C(1)-O(1)-Zn(1) 105.5(3), C(2)-N(1)-C(13) 119.9(3), C(2)-N(1)-Zn(1) 118.9(3), C(13)-N(1)-Zn(1) 121.2(2), N(1)-C(2)$\mathrm{C}(3)$ 134.5(4), N(1)-C(2)-C(1) 117.8(4), C(3)-C(2)-C(1) 107.7(4), O(1)$\mathrm{C}(1)-\mathrm{C}(11)$ 130.7(5), O(1)-C(1)-C(2) 122.7(4), C(11)-C(1)-C(2) 106.5(4), $\mathrm{C}(10)-\mathrm{C}(11)-\mathrm{C}(1)$ 132.9(5), $\mathrm{C}(12)-\mathrm{C}(11)-\mathrm{C}(1)$ 105.8(4). 1b. $\mathrm{Br}(1)-\mathrm{Zn}(1)$ 2.3266(6), $\quad \operatorname{Br}(2)-\mathrm{Zn}(1)^{\mathrm{i}} 1$ 2.4243(6), $\quad \operatorname{Br}(2)-\mathrm{Zn}(1)$ 2.5980(7), $\mathrm{Zn}(1)-\mathrm{N}(1)$ 2.073(3), $\mathrm{Zn}(1)-\mathrm{Br}(2)^{\mathrm{i}} 12.4243(6), \mathrm{Zn}(1)-\mathrm{O}(1)$ 2.483(3), O(1)-C(2) 1.223(5), $\mathrm{N}(1)-\mathrm{C}(1)$ 1.274(5), N(1)-C(13) 1.455(5), C(1)-C(11) 1.464(5), C(1)-C(2) 1.536(5); Selected Bond Angles in [ $\left.{ }^{\circ}\right]: \operatorname{Zn}(1)^{\mathrm{i}} 1-\operatorname{Br}(2)-\mathrm{Zn}(1) 88.50(2), \mathrm{N}(1)-$ $\mathrm{Zn}(1)-\operatorname{Br}(1) \quad 116.29(9), \mathrm{N}(1)-\mathrm{Zn}(1)-\operatorname{Br}(2)^{\mathrm{i}} 1$ 117.64(9), $\operatorname{Br}(1)-\operatorname{Zn}(1)-\operatorname{Br}(2)^{\mathrm{i}} 1$ 121.54(2), N(1)-Zn(1)-O(1) 74.91(11), Br(1)-Zn(1)-O(1) 89.52(7), $\mathrm{Br}(2)^{\mathrm{i}} 1-$ $\mathrm{Zn}(1)-\mathrm{O}(1)$ 84.01(7), N(1)-Zn(1)-Br(2) 96.30(9), $\operatorname{Br}(1)-\mathrm{Zn}(1)-\operatorname{Br}(2)$ 103.50(2), $\mathrm{Br}(2)^{\mathrm{i}} 1-\mathrm{Zn}(1)-\mathrm{Br}(2)$ 91.50(2), $\mathrm{O}(1)-\mathrm{Zn}(1)-\mathrm{Br}(2)$ 166.65(7), C(2)-O(1)-Zn(1) 105.8(3), C(1)-N(1)-C(13) 118.8(3), C(1)-N(1)-Zn(1) 118.6(3), C(13)-N(1)$\mathrm{Zn}(1) 122.4(2) \mathrm{N}(1)-\mathrm{C}(1)-\mathrm{C}(11)$ 134.2(4), N(1)-C(1)-C(2) 119.0(3), C(11)$\mathrm{C}(1)-\mathrm{C}(2)$ 106.9(3), O(1)-C(2)-C(3) 132.7(4), O(1)-C(2)-C(1) 121.4(4). 


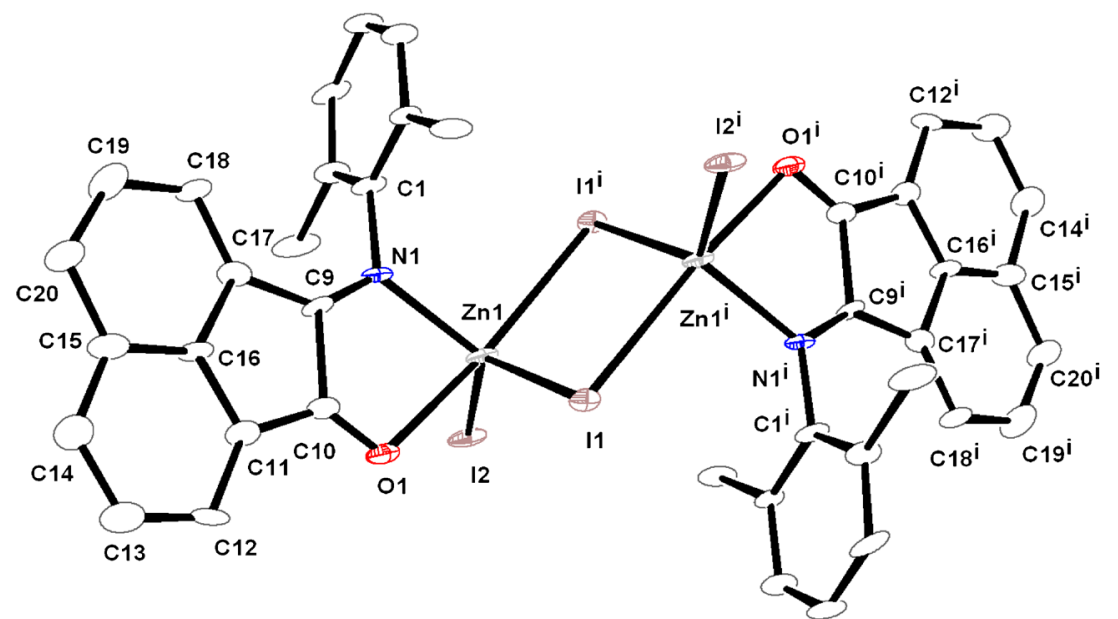

(c)

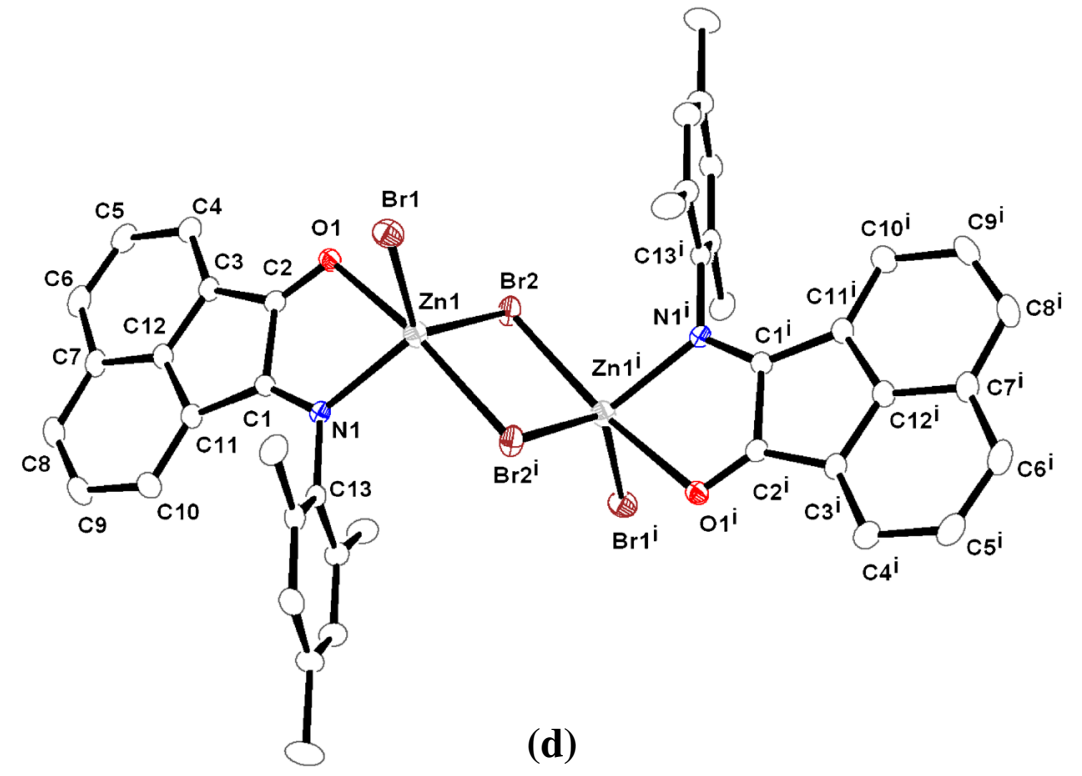

Figure 1. 1c. $\quad \mathrm{I}(1)-\mathrm{Zn}(1) \quad 2.6529(13), \quad \mathrm{I}(1)-\mathrm{Zn}(1)^{\mathrm{i}} 1 \quad 2.8263(15), \quad \mathrm{I}(2)-$ $\mathrm{Zn}(1)$ 2.5377(13), Zn(1)-N(1) 2.104(8), Zn(1)-O(1) 2.392(8), Zn(1)-I(1) 1 2.8263(15), O(1)-C(10) 1.222(14), N(1)-C(9) 1.259(13), N(1)-C(1) 1.452(11), $\mathrm{C}(2)-\mathrm{C}(1)$ 1.409(14); Selected Bond Angles in $\left[^{\circ}\right]$ : $\mathrm{Zn}(1)-\mathrm{I}(1)-\mathrm{Zn}(1)^{\mathrm{i}} 1$ 87.89(4), N(1)-Zn(1)-O(1) 76.0(3), N(1)-Zn(1)-I(2) 118.0(2), O(1)-Zn(1)-I(2) 91.63(19), N(1)-Zn(1)-I(1) 111.4(2), O(1)-Zn(1)-I(1) 80.23(18), I(2)-Zn(1)$\mathrm{I}(1) \quad 126.07(5), \quad \mathrm{N}(1)-\mathrm{Zn}(1)-\mathrm{I}(1)^{\mathrm{i}} 1 \quad 95.6(2), \quad \mathrm{O}(1)-\mathrm{Zn}(1)-\mathrm{I}(1)^{\mathrm{i}} 1 \quad 165.42(19)$, $\mathrm{I}(2)-\mathrm{Zn}(1)-\mathrm{I}(1)^{\mathrm{i}} 1$ 102.89(5), I(1)-Zn(1)-I(1) 1 92.11(4), C(10)-O(1)-Zn(1) 106.7(6), C(9)-N(1)-C(1) 119.0(8), C(9)-N(1)-Zn(1) 117.2(6), C(1)-N(1)$\mathrm{Zn}(1)$ 123.8(6). 1d. $\operatorname{Br}(2)-\mathrm{Zn}(1) 2.4512(7), \operatorname{Br}(2)-\operatorname{Zn}(1)^{\mathrm{i}} 12.5639(7), \operatorname{Br}(1)-$ $\mathrm{Zn}(1) 2.3435(7), \mathrm{Zn}(1)-\mathrm{N}(1)$ 2.104(4), Zn(1)-O(1) 2.414(3), Zn(1)-Br(2) 1 2.5639(7), $\mathrm{O}(1)-\mathrm{C}(2)$ 1.212(6), $\mathrm{N}(1)-\mathrm{C}(1)$ 1.286(6), N(1)-C(13) 1.442(5), $\mathrm{C}(1)-\mathrm{C}(11)$ 1.466(6), $\mathrm{C}(1)-\mathrm{C}(2)$ 1.535(6), $\mathrm{C}(2)-\mathrm{C}(3)$ 1.466(6); Selected bond Angles in [ $\left.{ }^{\circ}\right]: \operatorname{Zn}(1)-\operatorname{Br}(2)-\operatorname{Zn}(1)^{\mathrm{i}} 189.08(2), \mathrm{N}(1)-\operatorname{Zn}(1)-\operatorname{Br}(1)$ 114.62(10), $\mathrm{N}(1)-\mathrm{Zn}(1)-\mathrm{O}(1)$ 75.58(12), $\mathrm{Br}(1)-\mathrm{Zn}(1)-\mathrm{O}(1)$ 87.64(8), $\mathrm{N}(1)-\mathrm{Zn}(1)-\mathrm{Br}(2)$ 117.29(10), $\operatorname{Br}(1)-\operatorname{Zn}(1)-\operatorname{Br}(2)$ 122.18(3), O(1)-Zn(1)-Br(2) 82.14(8), N(1)$\mathrm{Zn}(1)-\operatorname{Br}(2)^{\mathrm{i}} 1$ 96.74(10), $\mathrm{Br}(1)-\mathrm{Zn}(1)-\mathrm{Br}(2)^{\mathrm{i}} 1$ 106.71(3), O(1)-Zn(1)-Br(2) 1 165.60(8), $\operatorname{Br}(2)-\operatorname{Zn}(1)-\operatorname{Br}(2)^{\mathrm{i}} 1$ 90.92(2), C(2)-O(1)-Zn(1) 107.3(3), C(1)$\mathrm{N}(1)-\mathrm{C}(13)$ 118.9(4), C(1)-N(1)-Zn(1) 117.3(3), C(13)-N(1)-Zn(1) 123.7(3), $\mathrm{N}(1)-\mathrm{C}(1)-\mathrm{C}(2)$ 117.6(4), O(1)-C(2)-C(3) 131.4(4), O(1)-C(2)-C(1) 122.1(4), $\mathrm{C}(3)-\mathrm{C}(2)-\mathrm{C}(1) 106.5(4)$. 
$(\mathrm{pz}=$ pyrazole $)$ reported by Chaudhury et al. ${ }^{28}$ and 1.994(2) - 2.050(2) Å observed for $\left[\left\{\mathrm{CH}\left(\mathrm{Ph}_{2} \mathrm{PNSiMe}_{3}\right)_{2}\right\}\right.$ $\left.\mathrm{ZnN}\left(\mathrm{SiMe}_{3}\right)_{2}\right]$ reported by Roesky et al. ${ }^{29}$ Three different $\mathrm{Zn}$-halide distances in each complex $[\mathrm{Zn}-\mathrm{Cl}$ 2.210(2), 2.309(2), 2.440(1), ̊ for 1a; Zn-Br 2.327(6), 2.424(6), 2.598(7) $\AA$ for 1b; Zn-I 2.536(1), 2.653(1), $2.826(2) \AA$ for $1 \mathrm{c}$ and $\mathrm{Zn}-\mathrm{Br}$ 2.343(7), 2.451(7), 2.564(7) $\AA$ for $2 \mathrm{~b}$ ] indicate that one halide ion is purely covalent bonded, whereas second halide ion is bonded covalently as well as in bridging fashion which elongate $\mathrm{Zn}$-halide distance slightly, and the third halide ion is purely a coordination bond and has the longest Zn-halide distance. Thus, an asymmetric attachment of the halide ions to the zinc centres are observed in each complexes. The average distance of 2.217(7) $\AA$ was observed as $\mathrm{Zn}-\mathrm{Cl}$ distance in BIANZnCl ${ }_{2}^{30}$ and 2.337-2.347 $\AA$ was reported as $\mathrm{Zn}-\mathrm{Br}$ distance ( $\mathrm{ZrBr} 2(\mathrm{TEEDA})$ ) (tetraethylethylenediamine) in literature. ${ }^{31}$ The Zn-I bond distance of 2.550(8)2.553(7) $\AA$ is reported for BIANZnI 2 by Schumann et al. ${ }^{30}$

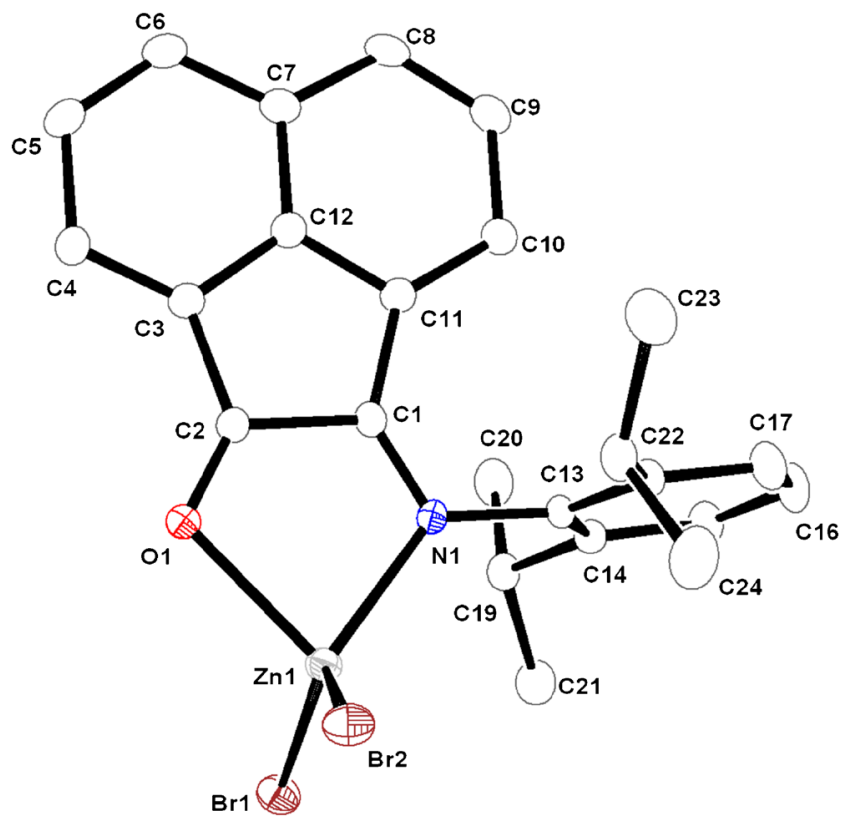

Figure 2. Solid-state structure of $\mathbf{3 b}$ showing the atom labelling scheme omitting hydrogen atoms for clarity. Selected bond lengths in [A]: $\mathrm{Zn}(1)-\mathrm{N}(1) 2.086(2)$, $\mathrm{Zn}(1)-\mathrm{O}(1)$ 2.162(2), $\mathrm{Zn}(1)-\mathrm{Br}(1) 2.3181(6), \mathrm{Zn}(1)-\mathrm{Br}(2)$ 2.3280(6), O(1)-C(2) 1.227(4), N(1)-C(1) 1.278(4), N(1)C(13) 1.460(4), C(1)-C(11) 1.460(4), C(1)-C(2) 1.539(4), $\mathrm{C}(2)-\mathrm{C}(3)$ 1.463(4); Selected bond angles in [ $\left.{ }^{\mathrm{O}}\right]$ : $\mathrm{N}(1)-\mathrm{Zn}(1)-$ $\mathrm{O}(1)$ 81.03(9), N(1)-Zn(1)-Br(1) 114.77(7), O(1)-Zn(1)$\mathrm{Br}(1)$ 107.52(6), N(1)-Zn(1)-Br(2) 113.13(7), O(1)-Zn(1)$\mathrm{Br}(2)$ 104.90(6), $\mathrm{Br}(1)-\mathrm{Zn}(1)-\mathrm{Br}(2)$ 125.08(2), C(2)-O(1)$\mathrm{Zn}(1)$ 109.00(19), C(1)-N(1)-C(13) 118.1(3), C(1)-N(1)$\mathrm{Zn}(1)$ 111.5(2), C(13)-N(1)-Zn(1) 130.30(19), N(1)-C(1)C(11) 135.3(3), N(1)-C(1)-C(2) 117.4(3), O(1)-C(2)-C(3) 132.4(3), O(1)-C(2)-C(1) 121.0(3), C(3)-C(2)-C(1) 106.5(3).
The monomeric zinc complex $\mathbf{3 b}$ crystallizes in monoclinic space group $P 2_{1} / \mathrm{c}$ having two independent molecules in the unit cell along with two dichloromethane molecules. The details of structural and refinement parameters of the complex $\mathbf{3 b}$ are given in table 1. The molecular structure of complex $\mathbf{3 b}$ is shown in figure 2. The central ion zinc is tetracoordinated through nitrogen and oxygen atoms present in the 2,6-diisopropylphenyl-BIAO ligand and two bromide ions attached to zinc. The geometry around the zinc can be best described as distorted tetrahedral. With respect to the dimeric complexes $\mathbf{1 a}-\mathbf{c}$ and $\mathbf{2 b}$, the monomeric form of $\mathbf{3 b}$ can be understood due to the presence of 2,6-isopropylphenyl group on the iminoacenapthenone moiety which prevents the formation of dimer. The Zn-O distances [2.162(2) and 2.154(2) $\AA$
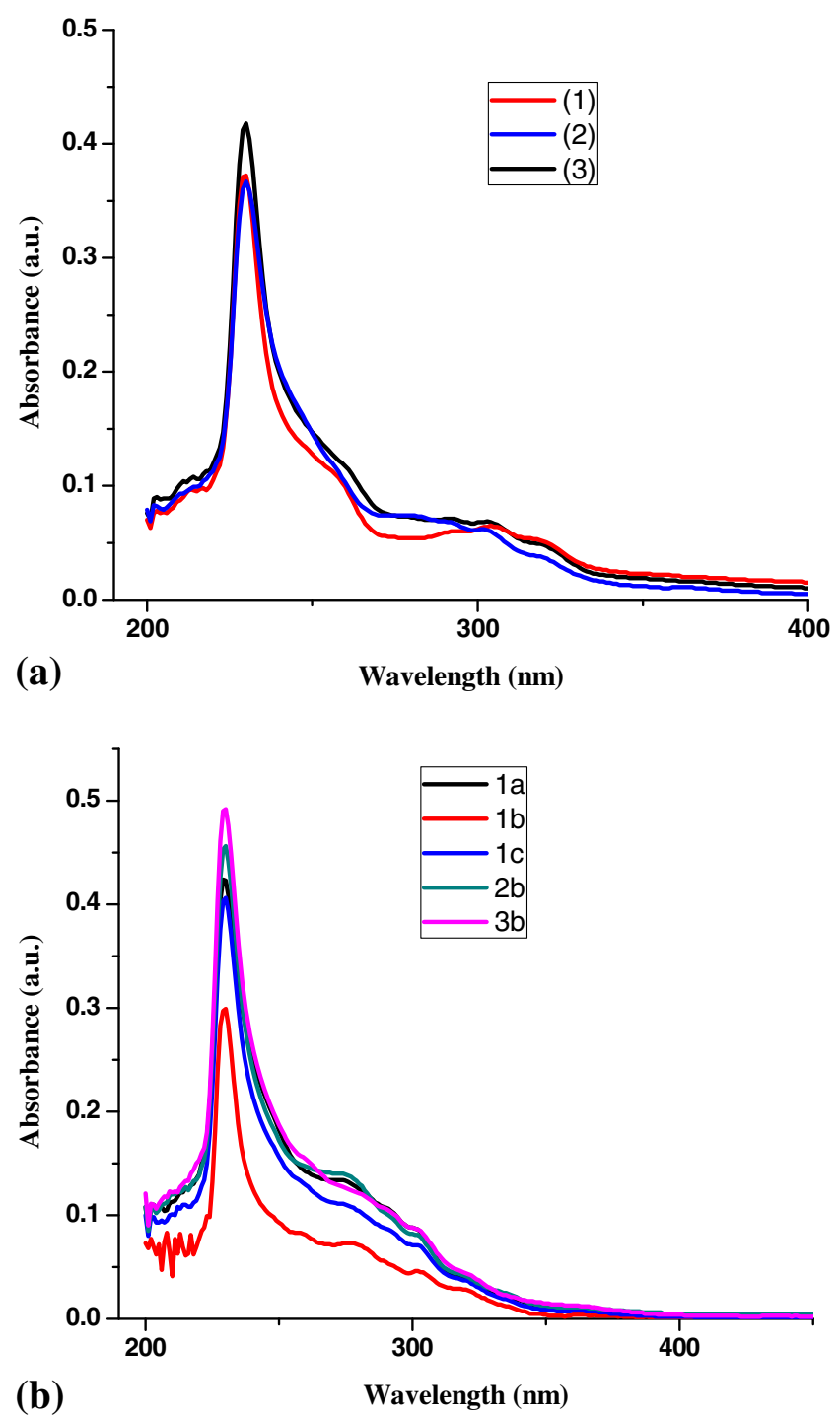

Figure 3. a-b. The UV-vis absorption spectra of ligands 1$\mathbf{3}$ and zinc complexes $\mathbf{1 a - c ,} \mathbf{2 b}$ and $\mathbf{3 b}$ in $\mathrm{CH}_{2} \mathrm{Cl}_{2}$ at room temperature $\left(3.207 \times 10^{-6} \mathrm{M}\right)$ respectively. 


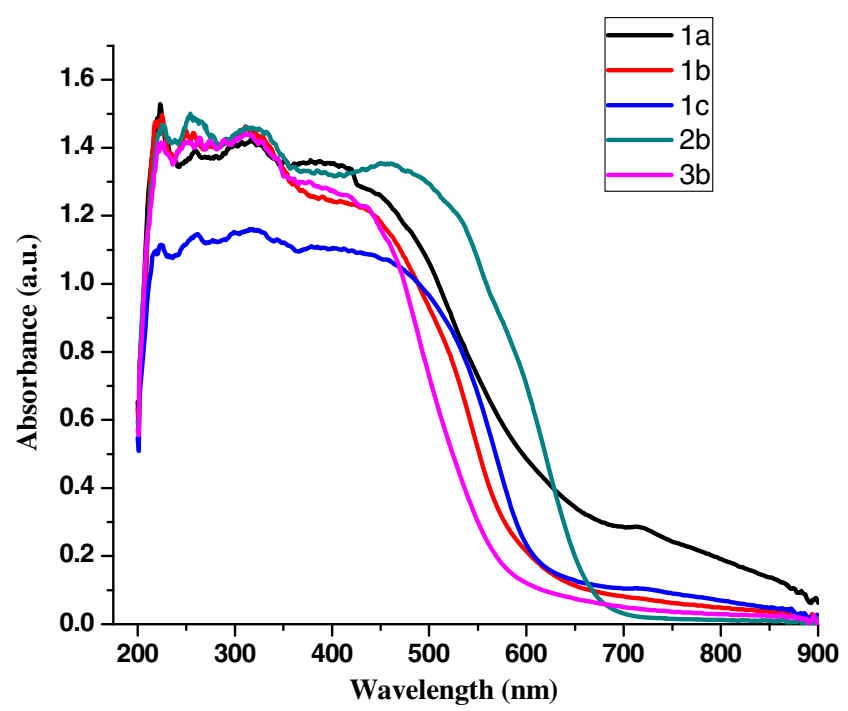

Figure 4. The solid state UV-vis absorption spectra of complexes $\mathbf{1 a}-\mathbf{c}, \mathbf{2 b}$ and $\mathbf{3 b}$.

for molecule 1 and 2 respectively] are slightly shorter than that of complexes $\mathbf{1 a}-\mathbf{c}$ and $\mathbf{2 b}$ (see above). This can be explained due to expansion of coordination number from four to five for zinc ion as we move from tetrahedral geometry of $\mathbf{3 b}$ to trigonal bipyramidal geometry of $\mathbf{1 a - c}$ and $\mathbf{2 b}$. Nevertheless, the Zn-N distances [2.086(2) and 2.105(2) $\AA$ for molecule 1 and 2 respectively] are in the similar range with that of $\mathbf{1 a - c}$ and $\mathbf{2 b}$. The $\mathrm{Zn}-\mathrm{Br}$ distances [2.318(6) and 2.328(6) A for molecule 1 and 2.307(6) and 2.332 (6) $\AA$ for molecule 2) are also similar with that of zinc complexes $\mathbf{1 b}$ and $\mathbf{2} \mathbf{b}$. In $\mathbf{3 b}$, the four membered zinc metallacycles Zn1-N1-C1-C2-O1 (molecule 1) and $\mathrm{Zn} 2-\mathrm{N} 2-\mathrm{C} 25-\mathrm{C} 26-\mathrm{O} 1$ (molecule 2) are formed and almost co-planar with the acenapthene plane (dihedral angle $6.79^{\circ}$ ).

\subsection{UV-visible spectra}

UV-visible absorption spectra of Ar-BIAO ligands 1, $\mathbf{2}$ and $\mathbf{3}$ (figure $3 \mathrm{a}$ ) were measured in dichloromethane at room temperature and displayed a nearly comparable absorption pattern at 230, $303 \mathrm{~nm}$. The absorption spectra of the ligands $\mathbf{1}, \mathbf{2}$ and $\mathbf{3}$ can be attributed to the $\pi \rightarrow \pi^{*}$ transitions and $\mathrm{n} \rightarrow \pi^{*}$ transitions respectively. The UV-visible absorption spectra of complexes $\mathbf{1 a}, \mathbf{1 b}, \mathbf{1 c}, \mathbf{2} \mathbf{b}$ and $\mathbf{3 b}$ (figure $3 \mathbf{b}$ ) were also measured in dichloromethane at room temperature and displayed a similar kind of absorption pattern at $230 \mathrm{~nm}$ for $\pi \rightarrow \pi^{*}$ transition. Upon coordination with zinc (II) ion, the absorption peaks are slightly shifted compared to that of the respective ligands. The solidstate UV-visible absorption spectra of $\mathbf{1 a}, \mathbf{1 b}, \mathbf{1 c}, \mathbf{2 b}$, 3b were significantly different from that of solution (figure 4). In the solid-state UV-visible absorption spectra of $\mathbf{1 a}, \mathbf{1 b}, \mathbf{1 c}, \mathbf{2 b}, \mathbf{3 b}$ a broad absorption peak from 250 to $500 \mathrm{~nm}$ were attributed to the $\pi$ to $\pi^{*}$ transition of ligand. In the solid-state UV-visible absorption spectra of all zinc (II) complexes, the $\pi \rightarrow \pi^{*}$ transition intensity is in the same order for complexes 1a, $\mathbf{1 b}$, $\mathbf{2 b}$ and $\mathbf{3 b}$ but for complex $\mathbf{1 c}$, the intensity drastically decreases compared to that of other complexes.

\section{Conclusion}

We have successfully synthesized and characterized four dimeric penta-coordinated zinc complexes $\left[\mathrm{ZnCl}_{2} \text { (2,6-dimethylphenyl-BIAO) }\right]_{2}$ (1a), $\left[\mathrm{ZnBr}_{2}(2,6-\right.$ dimethylphenyl-BIAO) $]_{2}$ (1b), [ZnI 2 (2,6-dimethylphenyl$\mathrm{BIAO})]_{2}$ (1c) and $\left[\mathrm{ZnBr}_{2}(\mathrm{Mes}-\mathrm{BIAO})\right]_{2}$ (2b) along with one tetra-coordinated monomeric zinc complex [ $\mathrm{ZnBr}_{2}($ Dipp-BIAO)] (3b). The molecular structures of all the complexes were established and they revealed a bidentate ligation from the Ar-BIAO ligands in each case through lone pairs of nitrogen and oxygen atoms. Thus, it was observed that by changing the steric crowding on the Ar-BIAO ligand, the nuclearity of the zinc complexes can be changed.

\section{Supplementary Information}

Crystallographic data (excluding structure factors) for the structures reported in this paper have been deposited with the Cambridge Crystallographic Data Centre as a supplementary publication no. CCDC 10036871003691. Copies of the data can be obtained free of charge on application to CCDC, 12 Union Road, Cambridge CB21EZ, UK (fax: + (44)1223-336-033; email: deposit@ccdc.cam.ac.uk).

\section{Acknowledgements}

This work was supported by the Council of Scientific and Industrial Research (CSIR) scheme ((No. 01(2530)/11/EMRII)) and start-up grant from IIT Hyderabad. S.A. thanks CSIR, India and K. N. thanks University Grant Commission (UGC), India for their PhD fellowship.

\section{References}

1. Sun H, Ritch J S and Hayes P G 2011 Inorg. Chem. 50 8063

2. Pastor M F, Whitehorne T J J, Oguadinma $\mathrm{P} O$ and Schaper F 2011 Inorg. Chem. Commun. 141737 
3. Drouin F, Oguadinma P O, Whitehorne $\mathrm{T}$ J J, Prud'homme R E and Schaper F 2010 Organometallics 292139

4. Boerner J, Floerke U, Doering A, Kuckling D, Jones M D, Steiner M, Breuning M and Herres-Pawlis S 2010 Inorg. Chem. Commun. 13369

5. Darensbourg D J and Karroonnirun O 2010 Inorg. Chem. 492360

6. Howard R H, Alonso-Moreno C, Broomfield L M, Hughes D L, Wright J A and Bochmann M 2009 Dalton Trans. 8667

7. Labourdette G, Lee D J, Patrick B O, Ezhova M B and Mehrkhodavandi P 2009 Organometallics 281309

8. Chisholm M H, Eilerts N W, Huffman J C, Iyer S S, Pacold M and Phomphrai K 2000 J. Am. Chem. Soc. 122 11845

9. Chakraborty D and Chen E Y -X 2003 Organometallics 22769

10. Zhao N, Chen L, Ren W, Song H and Zi G $2012 J$. Organomet. Chem $\mathbf{7 1 2} 29$

11. Zi G 2009 Dalton Trans. 9101

12. Zi G 2011 J. Organomet. Chem. 69668.

13. Xiang L, Wang Q, Song H and Zi G 2007 Organometallics 265323

14. Wang Q, Xiang L, Song H and Zi G 2008 Inorg. Chem. 474319

15. Zi G, Xiang L and Song H 2008 Organometallics 27 1242

16. Xiang L, Song H and Zi G 2008 Eur. J. Inorg. Chem. 1135

17. Bette V, Mortreux A, Savoia D and Carpentier J F 2004 Tetrahedron 602837

18. (a) Anga S, Paul M, Naktode K, Kottalanka R K and Panda T K 2012 Z. Anorg. Allg. Chem. 637 1311; (b) Anga S, Pal T, Kottalanka R K, Paul M and Panda T K
2013 Can. Chem. Trans. 1 105; (c) Anga S, Biswas S, Kottalanka R K, Mallik B S and Panda T K 2014 Can. Chem. Trans. 272

19. van Asselt R and Elsevier C J 1992 Organometallics 11 1999

20. Cavell K J, Stufkens D J and Vrieze K 1980 Inorg. Chim. Acta 47672

21. Reinhold J, Benedix R, Birner P and Hennig H 1979 Inorg. Chim. Acta 33209

22. (a) Jeon M, Han C J and Kim S Y 2006 Macromol. Res. 14 306; (b) Small B L, Rios R, Fernandez E R, Gerlach D L, Halfen J A and Carney M J 2010 Organometallics 29 6723; (c) Schmiege B M, Carney M J, Small B L, Gerlach D L and Halfen J A 2001 Dalton Trans. 2547

23. Kovach J, Peralta M, Brennessel W W and Jones W D 2011 J. Mol. Struct. 99233

24. Sheldrick G M SHELXS-97 Program of Crystal Structure Solution University of Göttingen, Germany 1997

25. Sheldrick G M SHELXL-97 Program of Crystal Structure Refinement University of Göttingen, Germany 1997

26. Guru S and Ramana Rao D V 1968 Z. Anorg. Allg. Chem. 362108

27. Bhattacharyya S, Kumar S B, Dutta S K, Tiekink E R T and Chaudhury M 1996 Inor. Chem. 351967

28. Seetawan U, Jugsujinda S, Seetawan T, Ratchasin A, Euvananont C, Junin C, Thanachayanot C and Chainaronk P 2011 Mater. Sci. Appl. 21302

29. Marks S, Köppe R, Panda T K and Roesky P W 2010 Chem. Eur. J. 167096

30. Fedushkin I L, Skatova A A, Eremenko O V, Hummert M and Schumann H 2007 Z. Anorg. Allg. Chem. 633 1739

31. Eckert P K, Vieira I S, Gessner V H, Börner J, Strohmann C and Herres-Pawlis S 2013 Polyhedron 49 151 